\title{
IN PERSONAM JURISDICTION IN MULTIPLE-PARTY SUITS
}

Except in rare situations, ${ }^{1}$ the courts in any state can exercise personal jurisdiction over only those individuals who are citizens of or found in that state or have such contacts in that state "that the maintenance of the suit does not offend 'traditional notions of fair play and substantial justice." "2 In most twoparty actions this rule is sufficiently flexible to provide a plaintiff with at least one state in which he can obtain personal jurisdiction over the defendant. However, in actions where the plaintiff must obtain personal jurisdiction over two or more parties, he may find that there is no single state in which they are all subject to in personam jurisdiction. This comment discusses this jurisdictional problem and possible solutions for it.

I

A prospective plaintiff with a cause of action against two or more persons can obtain legal relief when the dispute is over the title to land, ${ }^{3}$ when a single state can exercise personal jurisdiction over all potential defendants, or if in a suit against one defendant the others would not be considered "indispensable." If, however, the potential defendants are "indispensable," the plaintiff may

1 The federal courts have power to exercise a more extensive in personam jurisdiction when authorized by federal statute, e.g., Federal Interpleader Act, 62 Stat. 391 (1948), 28 U.S.C.A. $\$ 1335$ (1950); Fed. Rules Civ. Proc. 4(f).

2 International Shoe Co. v. Washington, 326 U.S. 310, 316 (1945). The "minimum contacts" test sets the constitutional limits to the in personam jurisdiction of states. Before a state court can exercise personal jurisdiction over a person outside the state who is not a citizen of that state it must be authorized by state legislation to serve such individual or corporation with process. For the purposes of this comment it will be assumed that all states have legislation enabling them to exercise personal jurisdiction in all cases in which they constitutionally may do so. This assumption is probably untrue of any state. Even the recently expanded Illinois statute does not seem to cover the cause of action arising from faulty goods transported into the state. That act provides: "Any person, whether or not a citizen or resident of this State, who in person or through an agent does any of the acts hereinafter enumerated, thereby submits said person, and, if an individual, his personal representative, to the jurisdiction of the courts of this State as to any cause of action arising from the doing of any of said acts: $(a)$ The transaction of any business within this State; $(b)$ The commission of a tortious act within this State; (c) The ownership, use, or possession of any real estate in this State; (d) Contracting to insure any person, property, or risk located within this State at the time of contracting." Ill. Rev. Stat. (1955) c. 110, \$17.

${ }^{3}$ See Currie, Full Faith and Credit to Foreign Land Decrees, 21 U. of Chi. L. Rev. 620 (1954), where the author argues that full faith and credit should be given to foreign decrees ordering conveyance of real property.

4 Since Erie v. Tompkins, 304 U.S. 64 (1938), it is probable that state law governs the determination of which parties are "indispensable" to an action in both state and federal courts. But see 3 Moore, Federal Practice $\$ 19.07$ (2nd ed., 1948). The rule laid down by the Supreme Court in the landmark case of Shields v. Barrow, 17 How. (U.S.) 129 (1854), is still widely cited as authority. In that case indispensable parties were defined as those "[p]ersons who not only have an interest in the controversy, but an interest of such a nature that a final decree cannot be made without either affecting that interest, or leaving the controversy in such a condition that its final termination may be wholly inconsistent with equity and in good conscience." Id., at 136. Under the indispensable party doctrine the courts attempt to minimize hardships 
not proceed against them separately; if no state can exercise personal jurisdiction over all of them, the plaintiff can not obtain legal relief. ${ }^{5}$ The person who desires to enforce a claim held jointly with another who refuses to sue is in a similar predicament. ${ }^{6}$ If the other party is indispensable to the suit and no state can exercise jurisdiction over both him and the proposed defendant, it will be very difficult for the plaintiff to obtain legal relief.?

A partial solution to the joinder problems would be effected by abandonment of the indispensable party concept; thereby each plaintiff could proceed alone against each defendant. However, not only would this fail in many cases to provide a desirable one-action remedy for plaintiffs with a joint claim against many defendants, but it would increase the number of situations where defendants are forced to defend their rights against multiple plaintiffs in separate suits. Under present law the latter situation occurs, for example, when a person holds contested title to all mineral rights in a tract of land. ${ }^{8}$ If the tract is divided into individually owned separate lots, the owner of the mineral rights is faced with as many potential suits as there are lots, for in a suit by one of the lot owners against the owner of the mineral rights his claim does not conflict with the claims of the other lot owners and therefore those parties are not indispensable and cannot involuntarily be joined in the action. ${ }^{9}$ Such situations are

to the parties in situations where the jurisdictional limitations make it possible to pass judgment binding on all the interested parties. It is clear that in some cases the courts' decisions produce more hardship than they alleviate. See, e.g., Carroll v. New York Life Ins. Co., 94 F.2d 333, 335 (C.A.8th, 1938).

${ }^{5}$ It might be possible for the plaintiff to wait for the absent defendant to pass through the state and then to serve process on him. For a discussion of the unfairness of subjecting a person who is only traveling through the state to the personal jurisdiction of that state, seeEhrenzweig, The Transient Rule of Personal Jurisdiction: The "Power" Myth and Forum Conveniens, 65 Yale L. J. 289 (1956), where the author makes the questionable argument that there is no historical basis in the common law for the exercise of this jurisdiction. See also, Foster, Place of Trial-Interstate Application of Intrastate Methods of Adjustment, 44 Harv. I. Rev. 41 (1930), where it is suggested that the unfairness of exercising jurisdiction over a transient could be eliminated without depriving the plaintiff of a forum by the courts' dismissal of these actions conditioned on the defendants making themselves available at a more convenient forum.

${ }^{6}$ E.g., in McAulay v. Moody, 185 Fed. 144 (C.C.Ore., 1911), where one of three joint owners of a promissory note sued the maker, a resident of Oregon, in an Oregon district court the action was dismissed because of the absence of the third owner, an indispensable party residing in Montana who refused to join in the action.

${ }^{7}$ Fed. Rules Civ. Proc. 19(a) states that "when a person who should join as a plaintiff refuses to do so, he may be made a defendant, or, in proper cases, an involuntary plaintiff." Unless there is a similar procedural rule for the courts in the state where the plaintiff in this situation sues he might lack the means for obtaining legal relief even if the absent party is subject to the court's personal jurisdiction.

${ }^{8}$ This factual situation was presented in Estes v. Shell Oil Co., 234 F.2d 847 (C.A.5th, 1956), where one of the lot owners sued for what he claimed was his share of the proceeds for oil which the defendant had pumped out of the ground over a twenty-year period.

${ }^{9}$ There is no provision in either the federal or state courts for a defendant to join nonindispensable plaintiffs to an action. See Fed. Rules Civ. Proc. 20(a). By seeking declaratory 
unfortunate, for the defendant who must defend multiple suits will lose much of the value of his property. Although it is usually true that the indispensable party concept has little value, in these situations it serves the useful purpose of limiting suits. ${ }^{10}$

If, in the example given in the preceding paragraph, the claims to the property are conflicting, the defendant can protect his property in one action by initiating suit in the nature of interpleader. ${ }^{11}$ Assuming diversity of citizenship, if all the claimants do not have sufficient contact in any one state to justify personal jurisdiction of a state court, ${ }^{12}$ the action may be commenced in a federal court; for under the Federal Interpleader $\mathrm{Act}^{13}$ an exception was made to the rules of personal jurisdiction of the federal courts and the federal district courts exercise nation-wide in personam jurisdiction.

Unfortunately the Interpleader Act may have caused more problems than it solved when it coupled its nation-wide service of process with extremely lenient jurisdictional and venue requirements. If there is any diversity of citizenship among the claimants and if the amount in controversy exceeds $\$ 500$, suit may be brought in any state where one of the claimants resides. While protecting the stakeholder from multiple liability, the Act gives the claimants almost no protection against inconvenient litigation, and an Oregon citizen might well have to assert his claim in Florida.

While the interpleader action is designed to protect the stakeholder against multiple liability, the impleader device serves a comparable purpose in safeguarding the defendant who, although liable to the plaintiff, is not ultimately liable for the amount in controversy. The device, for example, enables a party to an automobile accident to ensure that if he is held liable in a tort action by the injured person, his liability insurer will not escape responsibility by successfully denying, in a second suit, his liability to the plaintiff. By impleading the insurance company into the first suit the question of his liability will be adjudi-

judgments initially or by cross-claims the defendant can limit the number of suits to the number of different states in which claimants reside. Moreover, if the defendant wins the first suit, prospective claimants may well be deterred from litigating.

${ }^{10}$ Another situation in which the "indispensable party" concept plays a useful role is where one of the beneficiaries of a trust sues the trustees either for his share of the res or for an accounting, claiming mismanagement. When the other beneficiaries can justifiably be made "indispensable" to the action, the trustee is protected from multiple suits by the beneficiaries. Brown v. Christman, 126 F.2d 625 (App.D.C., 1942).

11 In an action "in the nature of interpleader" the stakeholder, who holds the disputed sum of money, claims the sum for himself. In the strict interpleader action the stakeholder claims no part of the res. Under present law there is no difference between these two actions for jurisdictional purposes.

12 It is possible that in some interpleader cases the state courts could exercise a quasi in rem jurisdiction over all the claimants. See Atkinson v. Superior Court, 49 Cal.2d 338, 316 P.2d 960 (1957).

1362 Stat. 391 (1948), 28 U.S.C.A. $\$ 1335$ (1950). 
cated only once. ${ }^{14}$ There is, however, nothing comparable to the Federal Interpleader Act's nation-wide process in impleader and if the court hearing the original case cannot exercise personal jurisdiction over the party to be impleaded, the action will proceed without him and the defendant will have no safeguard against inconsistent judgments.

To the parties making use of these multiple-party devices they may mean the difference between reasonable and exorbitant expense or the difference between enjoying or being deprived of legal relief. ${ }^{15}$ The fact that the restrictions on the in personam jurisdiction of the courts, which limit the usefulness of all these devices except interpleader, are a natural result of the historical development of this branch of the law ${ }^{16}$ in no way makes palatable the hardships caused.

\section{II}

It has been suggested that these hardships could be alleviated by having the federal court system adjudicate all multiple-party actions not justiciable in state courts. ${ }^{17}$ There is little reason to doubt the power of Congress to pass legislation

14 Fed. Rules Civ. Proc. 14 governs the impleader situation in the federal courts. The court may or may not, at its discretion, force a third-party defendant within the court's personal jurisdiction to become a party to the action.

${ }^{15}$ To the country's overcrowded courts these devices allow consolidation of several potential suits into one.

${ }^{16}$ The early view of the Supreme Court was that for jurisdictional purposes each state "possess[ed] and exercise[d] the authority of independent States. ..." Pennoyer v. Neff, 95 U.S. 714, 722 (1877). Thus each state could exercise jurisdiction over only those persons over whom it had physical power (those found within its borders and therefore within reach of the police power) or who owed allegiance to the state. Although the law of personal jurisdiction changed and the limitations becameless severe, it was not until 1945 in International Shoe Co. v. Washington, 326 U.S. 310 (1945), that the view that "[t]he foundation of jurisdiction is physical power..." (Holmes, J., in McDonald v. Mabee, 243 U.S. 90, 91 [1917), was expressly disapproved by the Supreme Court. Previous to this case the Court had resorted to the "consent" (Lafayette Insurance Co. v. French, 18 How. (U.S.) 404 [1855]; St. Clair v. Cox, 106 U.S. 350 [1922]; Pennsylvania Fire Ins. Co. v. Gold Issue Mining and Milling Co., 234 U.S. 93 [1917]), "presence" (New England Mutual Life Ins. Co. v. Woodworth, 111 U.S. 138 [1884]; Bank of America v. Whitney Central National Bank, 261 U.S. 171 [1923]), and "doing business" (International Harvester Co. v. Kentucky, 234 U.S. 579 [1914]; Rosenberg Co. v. Curtis Brown Co., 260 U.S. 516 [1923]), fictions to justify an expansion of the courts' personal jurisdiction, all of which were consistent with the idea that jurisdiction is based on physical power. The idea that an individual or corporation could be forced to consent to the personal jurisdiction of the state courts was based on the false notion that their activities could be curtailed by the states. But false or not, it rested on a concept of state power. Likewise, if a corporation was "present" or "doing business" in a state it could be argued that it was within the "power" of the state just as much as the individual found within its borders. Although the Supreme Court disavowed the "power" theory in International Shoe, a vestige of that concept remains in the rule that a state can exercise jurisdiction over only those who "have certain minimum contacts" within the state. Hanson v. Denckla, 257 U.S. 235 (1958).

For a recent discussion of the development of the law of personal jurisdiction see Kurland, The Supreme Court, the Due Process Clause and the In Personam Jurisdiction of State Courts from Pennoyer to Denckla: A Review, 25 U. of Chi. L. Rev. 569 (1958).

${ }^{17}$ Barrett, Venue and Service of Process in the Federal Courts-Suggestions for Reform, 7 Vand. I. Rev. 608 (1954). 
giving federal district courts jurisdiction over multiple-party suits involving imperfect diversity and allowing these courts to exercise nation-wide service of process. Both these provisions were incorporated in the Federal Interpleader Act ${ }^{18}$ and are generally accepted today. ${ }^{19}$ Venue requirements and transfer provisions ${ }^{20}$ could assure the parties a convenient forum. It has been argued that as long as the state courts are not adjudicating multiple-party cases, federal diversity jurisdiction might be justified even in the eyes of the strictest states' rights theorist. 21

It has also been suggested that Congress pass legislation requiring the states "in appropriate cases" to give full faith and credit to "civil process served anywhere in the United States" by a court in a sister state. ${ }^{22}$ Multiple-party actions would seem to head the list of "appropriate cases" and if such legislation were coupled with an increased use of forum non conveniens in the state courts, such a solution might be quite beneficial without undue harshness to

1862 Stat. 391 (1948), 28 U.S.C.A. $\$ 1335$ (1950).

19 It might be questioned whether the draftsmen of the Interpleader Act intended the courts to exercise jurisdiction in those situations where there is less than absolute diversity amang claimants. The general diversity statute gives the federal courts jurisdiction over controversies between "[c]itizens of different States," 62 Stat. 930 (1948), as amended, 28 U.S.C.A. $\$ 1332$ (Supp., 1958), and ever since Marshall's famous opinion in Strawbridge v. Curtiss, 3 Cranch (U.S.) 267 (1806), this statute has been held to require absolute diversity of citizenship between the plaintiffs and defendants. Before the 1948 amendments to the Interpleader Act, it called for jurisdiction in those cases where there were "two or more adverse claimants, citizens of different states." The diversity section was amended in 1948 to read "two or more adverse claimants, of diverse citizenship as defined in Section 1332 of this title." Had the draftsmen of the Act desired to make such a radical change in the law as to allow jurisdiction when there was less than absolute diversity among the claimants they surely could have made their intent clearer. Indeed, even Professor Chafee, a key figure in the passage of the Act, who believed that "the test for success of the federal legislation is the frequency with which interpleader has been granted in situations where state interpleader is impossible," Federal Interpleader Since the Act of 1936, 49 Yale L. J. 377 (1940), stated in 1932 that when "the effect of partial co-citizenship among the claimants ... is squarely raised it will probably bar relief unless ancillary jurisdiction can be established." Interpleader in the United States Courts, 41 Yale L. J. 1134, 1169 (1932). But the courts were almost unanimous in their view that as this was "remedial" legislation it should be broadly interpreted, and any diversity among the claimants was held to be sufficient for jurisdictional purposes. Jurisdiction has even been sustained when the stakeholder, one of the claimants and two of the three other joint claimants were citizens of the same state, the only diversity existing between these parties and one of three joint claimants. Haynes v. Felder, 239 F.2d 868 (C.A.5th, 1957). However, the Supreme Court has never explicitly approved jurisdiction in imperfect diversity cases. But see Dugas v. American Surety, 300 U.S. 414 (1937).

20 The present transfer provision for the federal courts is in 28 U.S.C.A. $\$ 1404$ (a). See Currie, Change of Venue and the Conflict of Laws, 22 U. of Chi. L. Rev. 405 (1955), for a discussion of the conflict-of-laws problems arising out of this transfer provision.

21 Barrett, Venue and Service of Process in the Federal Courts-Suggestions for Reform, 7 Vand. L. Rev. 608, 622 (1954).

22 Jackson, Full Faith and Credit-The Lawyer's Clause of the Constitution, 45 Col. L. Rev. 1, 22 (1945). Cook makes the same suggestion in the Logical and Legal Bases of the Conflict of Laws 99-100 (1949). 
defendants. ${ }^{23}$ Such legislation would, however, present complex constitutional quéstions. Can Congress, under authorization of the Full Faith and Credit Clause, pass legislation enabling the states to exercise jurisdiction which would violate due process in the absence of the statute? If so, how far can Congress go without violating the Due Process Clause? Given legislation under the Full Faith and Credit Clause, it is possible that the Supreme Court would allow in personam jurisdiction in multiple-party actions over individuals without contact in the forum state.

A similar solution might be provided by reciprocal state statutes. ${ }^{24}$ Each state would agree to recognize the service of process of courts in the other states in multiple-party actions and to enforce the judgments of those courts. These statutes would be comparable to those now widely in force permitting extradition of witnesses in criminal actions, and which have recently been held by the Supreme Court to be compatible with due process. ${ }^{25}$ The statutes might also provide that once a state acquires jurisdiction it would be free to transfer the case to another state which is a more convenient place of trial, in much the same way that transfer is now possible in the federal court system. ${ }^{26} \mathrm{It}$ is questionable, however, whether a state would agree to a transfer provision allowing the courts of another state to direct it to adjudicate a case. It is also questionable whether the states could increase their in personam jurisdiction in this manner, for, unlike Congress, the states are given no power in this area by the Constitution. But there is language in the recent opinion in New York v. $O^{\prime} \mathrm{Neill}^{27}$ which would support the' constitutionality of such statutes.

But there are two serious defects in these solutions. First, they require legislation. (At least fifty independent legislative acts would be required for the state statute solution.) It is unlikely that either Congress or the state legislatures are sufficiently interested in the problem to act. Secondly, by looking at only one side of the issue these "solutions" are likely to create more problems than they solve. ${ }^{28}$

${ }^{23}$ See Currie, Change of Venue and the Conflict of Laws, 22 U. of Chi. L. Rev. 405 (1955).

${ }^{24}$ E.g., Fla. Stat. Ann. (1955) \$\$942.01-942.06.

${ }^{25}$ New York v. O'Neill, 359 U.S. 1 (1959).

2672 Stat. 937 (1948), 28 U.S.C.A. \$1404(a) (1950).

${ }^{27} 359$ U.S. 1 (1959). "The Supreme Court of Florida held that inasmuch as what was ordered was to be carried on in a foreign jurisdiction, the Florida courts could not constitutionally be given jurisdiction to order it (citing Pennoyer v. Neff, 95 U.S. 714). However, the Florida courts had immediate personal jurisdiction over respondent by virtue of his presence within that State. Insofar as the Fourteenth Amendment is concerned, this gave the Florida courts constitutional jurisdiction to order an act even though that act is to be performed outside of the State." Id., at 8-9.

${ }^{28}$ The Federal Interpleader Act, 62 Stat. 391 (1948), 28 U.S.C.A. $\$ 1335$ (1950), is a good example of a legislative "solution" in this field. See text following note 13 supra, for a discussion of the problems caused by the Act. 
It is true that present law, in making some "contact" within a state prerequisite to personal jurisdiction, overemphasizes the importance of adjudicating in a convenient forum while failing to recognize the fact that in some cases the inconveniences of adjudicating are outweighed by the desirability of finding some forum in which to adjudicate the issue. Proposed changes in the law, however, tend to overemphasize the need for finding some forum in which to adjudicate multiple-party actions, while ignoring the fact that in a large country there will be some cases in which the inconveniences of any forum will outweigh the desirability of finding a forum in which to adjudicate. Transfer provisions are of no benefit when no convenient forum exists, and the doctrine of forum non conveniens has traditionally been used only in those situations in which a more convenient forum is available.

\section{III}

Perhaps a solution may be effected by judicial decision rather than by legislative action. The courts and not the legislatures are immediately faced with the problems in this area, and the courts, not the legislatures, have the flexible means for weighing the desirability of adjudicating an issue against the desirability of restricting adjudications to convenient forums. A possible judicial solution to the indispensable party situation would be to increase the scope of the class action to cover situations where there are only a few parties. A strange aspect of the present law is that a plaintiff may find it impossible to obtain relief against two parties, both indispensable, who live in different parts of the country, when, if he were claiming relief against numerous parties, he could obtain it by initiating a class action..$^{29}$ By expanding the scope of the class action an adjudication against two defendants could be made as easy as an adjudication against two hundred.

The solution, of course, would apply only to the joinder situation in which there are indispensable parties. ${ }^{30}$ Not only is a broader solution desirable-one covering all multiple-party actions-but it is unlikely that the Supreme Court would approve such expanded jurisdiction justified only by a change in terminology. A more direct solution would seem desirable, and the obvious one is to eliminate the present "contact" limitation on personal jurisdiction.

In International Shoe Co. v. Washington ${ }^{31}$ the Court repudiated the older power concept of personal jurisdiction and replaced it with a "fairness" test. ${ }^{32}$

${ }^{29}$ See 3 Moore, Federal Practice $\$ 23$ (2nd ed., 1948), and Multiparty Litigation in the Federal Courts, 71 Harv. L. Rev. 874 (1958), for a discussion of the problems peculiar to the class action, e.g., when it may be initiated and upon whom it is binding.

${ }^{30}$ Only if the parties are "indispensable" it is certain that they will be bound, regardless of their presence before the court, by the judgment in a class action. See 3 Moore, Federal Practice $\$ 23$ (2d ed., 1948).

31326 U.S. 310 (1945). Shoe.

32 See note 16 supra, for a discussion of the development of the law previous to International 
But the idea that a state could exercise jurisdiction over only those persons who had some contact within the state-an idea with origins in the power conceptwas incorporated into this fairness criterion.

[D]ue process requires only that in order to subject a defendant to a judgment in personam, if he is not present within the territory of the forum, he have certain minimum contacts with it such that the maintenance of the suit does not offend "traditional notions of fair play and substantial justice." ${ }^{33}$

It may be asked why "fair play and substantial justice" require that all persons subjected to the personal jurisdiction of a state court have "certain minimum contacts" with that state. Even if in some cases this limitation protects parties from having to defend actions in distant forums, in other cases the limitation serves no real purpose except to deprive the plaintiff of his legal remedy. The relationship between fair play and state lines is often vague at best.

An examination of Chief Justice Warren's majority opinion in Hanson v. Denckla, ${ }^{34}$ the most recent case upholding the "contact" limitation to the fairness test, helps to explain the Court's position. In that opinion the Chief Justice stated:

[I] $t$ is a mistake to assume that this trend [towards more flexible rules governing in personam jurisdiction] heralds the eventual demise of all restrictions on the personal jurisdiction of state courts... Those restrictions are more than a guarantee of immunity from inconvenient or distant litigation. They are a consequence of territorial limitations on the power of the respective states..$^{35}$

The Court, then, did not have to wrestle with the proposition that the contact doctrine is a rather arbitrary, one-sided way to protect a party from inconvenient litigation, for it justified the doctrine on other grounds. But what is meant by the statement that the contact restrictions on personal jurisdiction "are a consequence of territorial limitations on the power of the respective states"? Surely the Court was not referring to physical "power," for this was the concept repudiated in International Shoe. Nor was the Court referring to restrictions placed on the states' personal jurisdiction by the fairness test, for that test is a protection from "inconvenient or distant litigation" and these restrictions "are more than" that.

The only other conceivable explanation for this restriction is that it is a requirement of state sovereignty. "Sovereignty" is a difficult concept in relation to independent nations. What "state sovereignty" entails presents equally

${ }^{33}$ International Shoe Co. v. Washington, 326 U.S. 310, 316 (1945).

34357 U.S. 235 (1958).

${ }^{35} \mathrm{Id}$., at 250 . It is open to question whether the dissent by Black, J., indicates that the Court is unanimous in its view of the vitality of the contact doctrine or whether a minority would discard it were the question squarely presented. "Of course we have not reached the point where state boundaries are without significance, and I do not mean to suggest such a view here. There is no need to do so." Id., at 260. 
difficult problems. But it may be agreed that a state is "sovereign," as that term is used in our federal scheme of government, only if its citizens and the activities within the state are governed exclusively by the laws of that state and the federal government. No state, then, can make laws governing the activities of citizens of other states except to the extent to which those persons have contact with the state. It is, therefore, important that in each controversy a rational determination be made as to which state's substantive law governs it. But the question of jurisdiction, of finding a forum in which to adjudicate a case, and the question of which law should be applied are independent of each other. Granted that Pennsylvania cannot pass laws governing New York citizens who have had no contact with Pennsylvania, it does not seem to detract from New York's "sovereignty" when a Pennsylvania court applies New York law when adjudicating a controversy. State sovereignty should be protected by rules of the conflicts of laws, not those concerning personal jurisdiction. ${ }^{36}$ The contact restrictions on the states' personal jurisdiction are justified, then, not by any concept of state sovereignty, nor by the physical power or fairness concepts, nor by any other concept yet articulated by the Court. ${ }^{37}$ This is an area of the law where "old dogma has been destroyed [but] new doctrine to replace it has not been firmly fashioned." 38

As the law develops the Court will be faced with the choice of justifying the contact doctrine or discarding it. The only justification for this limitation on the states' personal jurisdiction is that it affords protection against distant, inconvenient litigation. When it is realized that this is the only justification, the Supreme Court will have to decide whether there is more likelihood of "fair play and substantial justice" with the contact limitation to the fairness doctrine or without this limitation. The argument for the limitation must rest on the protection it affords. The argument against it will point out that it equally "protects" the residents of Gary, Indiana, and Los Angeles, California, from having to defend a suit in Chicago, and that often the desirability of this pro-

${ }^{36}$ There is no question but that the problems in the area of conflict of laws are of great magnitude and that by eliminating the contact doctrine the number of times these problems arise will increase. For a recent discussion of these problems see Currie, The Constitution and the Choice of Law: Governmental Interests and the Judicial Function, 26 U. of Chi. L. Rev. 9 (1958).

${ }^{37}$ Nor do any of the standard justifactions for federalism require this limitation. The oftrepeated arguments for federalism are: (1) a decentralized government is more efficient and a greater safeguard against tyranical power than is a centralized government with an everexpanding bureaucracy; (2) local administrators have the greatest knowledge with which to deal with local problems; and (3) the many governments within the nation make experimentation on a less than nation-wide scale possible, and critical comparisons can be made of the various states' institutions. The defense of federalism in the Federalist is more on the negative side-the various states will check evil influences before they permeate the country as a whole. The Federalist Nos. 3, 9, 10, 51 (1894).

${ }^{28}$ Kurland, The Supreme Court, the Due Process Clause and the In Personam Jurisdiction of State Courts from Pennoyer to Denckla: A Review, 25 U. of Chi. $\mathrm{L}_{\text {, Rev. }}$ 569, 623 (1958). 
tection is outweighed by the desirability of giving the plaintiff a forum in which to adjudicate his claim, especially in the multiple-party actions.

In reply it will perhaps be urged that without the contact limitation a judge might abuse his discretionary powers and apply the fairness test in such manner as to disregard the defendants' hardships in traveling great distances to the forum. ${ }^{39}$ But to be weighed against this are benefits of greater range in the courts' discretion. Unhampered by the contact limitation the judge in each joinder action could weigh the fairness to all the parties in (1) proceeding with the action in the absence of those parties not before the court, (2) asserting personal jurisdiction over the absent parties and adjudicating the controversy with all of them present, or (3) dismissing the action..$^{40}$ In an impleader action he would be free to proceed without the absent third party or exercise personal jurisdiction over him. In an interpleader action he would be free to exercise jurisdiction over the various claimants or dismiss the action. In each case the judge would consider the nature of the dispute, the geographical locations and interests of the parties, and the availability of alternate forums. He would make that decision which he believed would best promote."fair play and substantial justice." 41

${ }^{39}$ The possibility of judicial abuse or indiscretion in this matter should not be ignored. Nor is the right to appeal much of a safeguard, for the cost and inconvenience of defending one's self before an appellate court can be just as great as that of defending one's self on the trial level. On the other hand, the exercise of discretionary jurisdiction over individuals is not new to American courts. They exercise jurisdiction today in impleader, permissive joinder and permissive intervention cases. Further, they exercise a discretionary jurisdiction over those cases in which they determine whether or not an absent party is "indispensable" to the action. The possibility of abuse would not seem to be much greater if the court's discretion extended to parties residing outside the state. The possibility that does exist might be lessened by the courts fixing costs at a higher level, much like the English courts do, thus deterring plaintiffs from bringing nuisance suits. This deterrent would not be great, however, in the case of the impecunious plaintiff.

Perhaps the possibility of abuse is great enough to justify the retention of the contact requirement in two-party suits while dropping the requirement only in multiple-party actions. There is surely some strength in the position that in two-party actions, where some forum always exists and there is little danger of multiple suits, the plaintiff, who desires to change existing relationships, should have to go to the trouble of finding a forum convenient to the defendant.

${ }^{10}$ In the case of the defendant desiring to join plaintiffs to an action to avoid the possibility of multiple suits, e.g., the mineral rights case discussed in text at note 8 supra, the courts might feel more free to find the other plaintiffs "indispensable" to the suit when such a finding did not mean automatic dismissal.

41 The amount in dispute might well be one of the factors to be considered. A party might in all fairness be asked to travel across the country to defend a claim for $\$ 10,000$ when it would be unfair to make him do so if the claim were for only $\$ 500$. This factor was apparently given little consideration when the Federal Interpleader Act was drafted. 